\title{
Interrelationships and Differences of Brachial-Ankle Pulse Wave Velocity (baPWV), Body Composition and Cardiovascular Variables between Genders Who Have Been Exercised or Not in Elderly
}

\author{
Jong-Woo Lee ${ }^{1}$, Dae-Sik Kim² ${ }^{2}$ Eun-Kyung $\mathrm{Cho}^{2}$

\section{운동참여 여부와 성별에 따른 노인의 맥박파전파속도, 신체구성과 심혈관계 변인의 상관성 및 재변인의 차이}

\author{
이종우 ${ }^{1}$, 김대식 $^{2}$, 조은경 ${ }^{2}$ \\ ${ }^{1}$ 고려대학교 안산병원 신경과, ${ }^{2}$ 동남보건대학교 임상병리과
}

\begin{abstract}
This study sought to investigate interrelationships and differences of brachial-ankle pulse wave velocity (baPWV), body composition and cardiovascular variables between genders who have been exercised or not in elderly. One hundred fifty participants were classified four groups. Especially out of variables, in male elderly group who had participated in exercise program the PWV range were significantly correlated with muscle mass ( $r=0.357, p=0.026)$, SBP $(r=0.468, p=0.003)$, right baPWV $(r=0.406, p=0.010)$, and left baPWV $(r=0.333, p=0.038)$. In male elderly group who had not participated in exercise program, the PWV range were significantly correlated with heart rate $(r=0.395, p=0.014)$, right baPWV $(r=0.598, p=0.000)$, and left baPWV $(r=0.602, p=0.000)$. In female elderly group who had participated in exercise program, the PWV range were significantly correlated with name of diagnosis $(\mathrm{r}=0.321, p=0.044)$, SBP $(\mathrm{r}=0.399, p=0.011)$, DBP $(\mathrm{r}=0.545$, $p=0.000)$, right baPWV $(r=0.648, p=0.000)$, and left baPWV $(r=0.676, p=0.000)$. In female elderly group who had not participated in exercise program, the PWV range were significantly correlated with age $(r=0.471, p=0.003)$, right baPWV $(r=0.836, p=0.000)$, and left baPWV $(r=0.801, p=0.000)$. The PWV among four groups were not significant different after experiment. However, there were significant differences in the waist/hip ratio $(F=9.197, p=0.000)$, muscle mass $(F=74.295$, $p=0.000)$, and \%fat $(\mathrm{F}=35.045, p=0.000)$ from body composition. And there were significant differences in the SBP (F=3.525, $p=0.017)$ after experiment. In conclusion, these data show that regular exercise is associated with arterial compliance (PWV range, right or left PWV) and differed from genders. In other words, this paper may support the concept that regular exercise program may exert a protective effect on arterial compliance, body composition and cardiovascular systems.
\end{abstract}

Key words: Arterial compliance, Brachial-ankle pulse wave velocity, Body composition variable, Cardiovascular variable

This is an Open Access article distributed under the terms of the Creative Commons Attribution Non-Commercial License (http://creativecommons.org/licenses/by-nc/4.0) which permits unrestricted non-commercial use, distribution, and reproduction in any medium, provided the original work is properly cited.

Copyright @ 2016 The Korean Society for Clinical Laboratory Science. All rights reserved.
Corresponding author: Eun-Kyung Cho Department of Clinical Laboratory Science, Dongnam Health University, 50

Cheoncheon-ro 74-gil, Jangan-gu, Suwon 16328, Korea

Tel: 82-31-249-6419

Fax: 82-31-249-6410

E-mail: ek991012@hanmail.net

Received: August 4, 2016 Revised $1^{\text {st: }}$ September 20, 2016

Revised 2 ${ }^{\text {nd }}$ : October 19, 2016

Revised 3 ${ }^{\text {rd: }}$ November 2, 2016 Accepted: November 2, 2016 


\section{서 론}

최근 건강에 대한 관심이 증가하면서 대부분의 노인들은 무병장 수보다도 더 활력 있고 건강한 노후의 삶을 원하게 되었다. 청장년 기를 지나 노년에 이르게 되면, 신체 각 기능이 저하되고, 신체활동 영역이 감소하여 여러 가지 질환에 쉽게 노출되는 것이 사실이다. 특히 심장병을 비롯한 심혈관계통의 질환은 한번의 발병으로 치명 적인 영향을 미치기 때문에 질환을 조기에 진단하고 예방하는 것이 중요하다. 심혈관계 질환에는 고혈압, 동맥경화, 뇌졸중 및 심근경 색 등이 있으며[1], 전 세계적으로 가장 흔한 질병 및 사망 원인의 하 나이다[2]. 심혈관계 위험 요소들은 복합적으로 작용하여 질환을 발생시킬 수 있는 가능성을 한층 높일 수 있기 때문에 위험 요소를 제거하거나 영향력을 감소시키기 위한 연구가 연속적으로 진행되 었다. 다수의 연구결과에 의하면 규칙적인 유산소성 운동은 심혈관 계 질환의 발생 위험도를 낮출 수 있다고 밝히고 있다[4]. 특히, 고 령자도 활기차게 걷기, 수영, 자전거 등의 골격근과 관절에 적당한 충격을 제공하는 유산소성 운동을 실시할 경우 최대산소섭취량이 유지되거나[4], 개선도 가능한 것으로 보고되고 있다[5]. 심혈관 질 환의 주 발병기전인 동맥경화증은 인슐린 저항성, 고혈당, 고중성 지방혈증, 염증반응, 내피세포기능장애 등으로 설명 되어지며, 내 피세포기능장애(endothelial dysfunction)는 노화현상의 일환으 로 간주되던 것이 최근 많은 연구들을 통해 만성 염증반응에 의한 것으로 밝혀지고 있다[6]. 이와 같은 혈류의 역동학적 상태를 평가 할 수 있는 객관적 지표들은 기술적 한계와 효용적인 문제로 인해 오랜 동안 간과되어 왔으나 최근 다양한 기법을 통한 비관혈적 혈 류역동학적 동맥경화증 평가지표들의 이용이 가능해졌으며[7], 동 맥벽 경화도를 계측하는 생리학적 검사법인 맥박파전파속도 (pulse wave velocity, PWV), 탄성(Compliance), 팽창성(Distensibility), 경직지수(Stiffness index $\beta$ ), 증가지수(Augmentation index) 등 여러 지표가 이용되고 있다[8]. 이중 PWV는 동맥의 두 지점 사이를 통과하는 맥파의 속도로, 동맥 경직도의 표지자로 근 래 많이 사용되고 있으며[8], 대표적인 동맥벽 경화도의 지표로써 국제적으로 통용되고 있다[9]. 즉, 맥박파전파속도는 동맥경화의 독립적인 위험인자임과 동시에 사망률을 예측하는 인자로 사용될
수 있으며[10], 예후 예견인자로도 유용하다고 한다[11]. 구체적으 로 동맥의 맥박파전파속도를 결정하는 중요한 혈역학적 인자인 동 맥의 경직도를 생체를 통하여 직접적으로 평가함으로써[12], 심혈 관 질환과의 관련성 및 조기진단에 이용하고자 하는 연구가 많이 이루어지고 있으며, 최근 운동이 혈관탄성의 변화에 미치는 영향과 순환계의 정상적 유지와 순환계질환의 개선과의 상관성에 대한 연 구가 활발히 진행되고 있고, 유산소성 운동에 대한 효과 및 운동선 수들에 대한 맥박파전파속도 반응성 등에 대하여 많은 연구가 이루 어져 오고 있다[13]. 그러나 전술한 많은 선행연구의 결과들은 일관 성이 다소 부족하고, 연구 대상 등이 젊은 사람들에게만 초점이 맞 추어져 있을 뿐만 아니라 성별간의 차이 등이 명확히 구분되어 있 지 않아 이에 대한 종합적인 연구가 필요한 것으로 생각되어 본 연 구에 착수하게 되었다.

\section{재료 및 방법}

\section{1. 연구 대상}

본 연구는 안산시 $\mathrm{K}$ 병원 N연구소에 내원하는 노인 154 명을 대 상으로 실시하였으며, 규칙적인 운동을 수행해온 노인남성 39명 (이하, 운동군M)과 운동을 수행해 오고 있지 않은 동일 연령대의 노 인남성 38 명(이하, 통제군 $\mathrm{M}$ ), 규칙적인 운동을 수행해온 노인여성 40명(이하, 운동군F)과 운동을 수행해 오고 있지 않은 동일 연령대 의 노인여성 37 명(이하, 통제군F)을 총 네그룹으로 구분하였다. 운 동군에 속한 남녀 집단은 최근 2 3년 이내 주3 5회, 1 회 30분 1 시간 유산소성 운동(걷기, 등산)을 규칙적으로 실행하고 있는 노 인들로 구성하였으며, 통제군은 최근 2 3년 이내 규칙적인 운동 을 하지 않은 노인들로 구성하였다. 연구를 진행하기 전에 연구과 정 전반에 걸쳐 대상자들의 검사결과에 대한 연구활용동의서를 받 았으며, 윤리적 측면을 고려하고, 개인식별 자료는 직접 명시하지 않았으며, 유추하여 신상을 파악할 수 있는 어떠한 자료도 제시하 지 않았다. 본 연구에 참여하였던 피험자들의 신체적 특성은 Table 1 과 같다.

Table 1. Physical characteristics of the subjects

\begin{tabular}{|c|c|c|c|c|c|c|}
\hline Gender & Groups & Age (yr) & Height $(\mathrm{cm})$ & Weight (kg) & Body fat (\%) & Number of diseases \\
\hline \multirow[t]{2}{*}{ Male } & Exercise $(n=39)$ & $68.41(4.87)$ & $165.30(4.64)$ & $67.96(8.98)$ & $27.34(5.47)$ & $1.58(0.49)$ \\
\hline & Control $(n=38)$ & $70.84(6.96)$ & $164.68(4.72)$ & $64.47(8.23)$ & $26.67(5.99)$ & $1.473(0.50)$ \\
\hline \multirow[t]{2}{*}{ Female } & Exercise $(n=40)$ & $68.70(3.79)$ & $151.55(5.49)$ & $58.05(8.18)$ & $36.83(6.68)$ & $1.60(0.49)$ \\
\hline & Control $(n=37)$ & $69.70(5.18)$ & $150.88(5.26)$ & $58.20(8.10)$ & $37.37(6.20)$ & $1.64(0.48)$ \\
\hline \multicolumn{2}{|c|}{ F-value $(p)$} & $1.659(0.178)$ & $95.596(0.000)$ & $13.123(0.000)$ & $35.045(0.000)$ & $0.843(0.472)$ \\
\hline
\end{tabular}




\section{2. 측정 방법}

모든 변인의 측정은 오전 9시 12시에 실시하였고, 측정 실시 전 피험자들에게 측정 목적과 필요성 및 방법을 설명하였다.

\section{1) 위팔-발목 맥박파전파속도(baPWV) 측정 분석 방법}

10 분간 누워 휴식을 취한 후 Pulse waveform analyzer (Nippon Colin, Komaki, Japan)를 이용하여 자동적으 로 기록되는 혈압과 심전도 감시 하에 $\mathrm{baPWV}$ 를 측정 하였다. 전극을 환자의 좌흉골 변 연에 부착시키고 사지에 혈압 커프를 감게 된다. 커프는 맥파형 크 기를 감지할 수 있는 plethysmographic sensor와 혈압을 감지하 는 oscillometric pressure sensor로 연결되어 있다. 또한 신장을 이용하여 계산된 상완과 발목 사이의 거리와 그 거리를 통과하는데 소요되는 시간이 측정되어 양측 $\mathrm{baPWV}$ 가 산출되며 총 검사시간 은 5 분이 소요되었다.

2) 신체구성 변인 측정 분석 방법

(1) 체격 측정

신장은 $0.01 \mathrm{~cm}$ 단위까지 측정하며, 체중은 $0.01 \mathrm{~kg}$ 단위까지 측정하였다. 체중 측정 시 가벼운 옷차림으로 측정하였으며, 신장 측정 시 맨발로 자연스럽게 직립자세를 취하게 하였다. 요위 측정 시에는 정상적으로 숨을 내쉰 상태에서 몸통의 가장 얇은 부위의 둘레를 편안한 상태에서 측정하였으며, 둔위 측정 시에는 가장 돌 출된 부위의 둘레를 측정하였다.

(2) 신체구성 측정

신체구성 측정은 Inbody520 체지방측정기(Biospace, Cheonan, Korea)를 이용하여 체지방율(\%Fat), 근육량(mass)등을 측정하였 다. 피험자는 양말을 벗고 Inbody520에 올라서서 발 뒷꿈치를 뒤 쪽의 동그란 발 전극에 맞추고 발 앞부분은 앞쪽의 타원형 발 전극 에 맞추었다. 손으로 전극봉을 잡아 엄지 손가락은 위쪽 동그란 전 극봉에 놓고 나머지 네 손가락은 모두 아래쪽의 긴 전극을 감싸 쥐 게 하였다. 그 후 팔꿈치를 펴고 겨드랑이와 몸통이 닿지 않도록 약 15 도 정도로 편하게 벌린 후 측정이 완료될 때까지 올바른 측정자 세가 유지되도록 하며, 약30초 후에 체지방율(\%Fat), 근육량 (mass) 등의 값이 자동으로 출력된다.

\section{3) 심혈관계 변인 측정 분석 방법 \\ (1) 혈압 측정}

검사실 도착 후 10 분간 안정을 취한 뒤 피험자가 의자에 앉아 편 안한 자세를 취하게 하고 오른팔의 손바닥을 위로 한 후 상완 동맥 의 박동이 가장 잘 촉지 되는 곳에서 $2 \sim 3 \mathrm{~cm}$ 위에 커프(bladder
폭: $12 \mathrm{~cm}$, 길이: $23 \mathrm{~cm}$ ) 를 감고 청진기를 댄 후 맥박이 촉지 되지 않은 점보다 압력을 $20 \sim 30 \mathrm{mmHg}$ 로 올려 1초에 2 4 $\mathrm{mmHg}$ 의 속도로 내리면서(감속속도가 측정실수를 야기 시킬 수 있기 때문), 수은주의 눈금을 눈높이에서 읽으며 Korotkoff sound phase 1 (혈 압 측정시 처음 들리는 약하나 깨끗하면서 '뚜뚜’라는 소리로 적어 도 2번 이상 연속적으로 들리는 소리)을 수축기 혈압으로 Korotkoff sound phase 5 (소리가 완전히 사라지는 단계)를 이완기 혈압으로 하였으며, 30 초간격으로 2 번 측정하여 그 값을 평균하여 산출하였다.

(2) 심박수 측정

검사실 도착 후 10 분간 안정을 취한 뒤 피험자가 의자에 앉아 편 안한 자세를 취하게 하고, 요골동맥에서 촉지 법에 의해 1 회에 1 분 동안 30초 간격으로 3 번 측정하여 그 값을 평균하여 산출하였다.

\section{3. 연구방법 및 통계분석}

본 연구에서 얻어진 모든 자료는 통계프로그램 SPSS 버전 18.0 (SPSS, Chicago, USA)을 이용하여 전산처리 하였으며, 모든 자료 에 대하여 평균과 표준편차를 산출하였다. 한편, 신체적 특성에 대 한 동질성 검증을 위하여 일원변량 분산분석을 실시하였고, 본 연 구를 분석하기 위하여 첫째, 위팔-발목 맥박파전파속도의 상태에 영향을 미칠 수 있는 성별과 운동력을 고려하여 집단을 분류한후 상관관계를 알아보았다. 둘째, 성별과 운동력의 구분 없이 전체 집 단에 있어 좌우측 위팔-발목 맥박파전파속도(이하, baPWV), 신체 구성 변인(신장, 체중, 근육량 등) 및 심혈관계 변인(수축기혈압, 이 완기혈압, 심박수) 간에 일원변량 분산분석 후 Tukey post-hoc을 실시하였다. 본 연구의 가설 수락기준은 유의도 $\alpha=0.05$ 수준으로 하였다.

\section{결 과}

\section{1. 집단별 위팔-발목 맥박파전파속도, 신체구성, 심혈관계 변인의 차이}

1) 집단별 위팔-발목 맥박파전파속도 변인의 차이

실험 종료 후 집단별 위팔-발목 맥박파전파속도 변인에 대한 평 균과 표준편차는 Table 2 와 같으며, 이에 대한 일원변량 분산분석 과 사후검정의 결과는 Table 3 과 같다.

(1) 우측 위팔-발목 맥박파전파속도의 분산분석 및 사후검정 결과 Table 2에 제시된 우측 위팔-발목 맥박파전파속도(right baPWV) 에 대한 일원변량 분산분석 결과와 이에 대한 Tukey 사후검정 결과 는 Table 3과 같다. Table 2에서 노인남성 운동군과 통제군의 right $\mathrm{baPWV}$ 는 각각 $1655.84( \pm 340.93) \mathrm{cm} / \mathrm{sec}$ 와 $1703.31( \pm 283.77)$ $\mathrm{cm} / \mathrm{sec}$ 씩으로 $2.87 \%$ 의 차이율을 보였고, 노인여성 운동군과 통 
Table 2. Differences of baPWV variables among total groups

\begin{tabular}{|c|c|c|c|c|c|c|c|c|c|}
\hline \multirow{3}{*}{ Genders } & \multicolumn{9}{|c|}{ Groups } \\
\hline & \multicolumn{3}{|c|}{ right baPWV $(\mathrm{cm} / \mathrm{sec})$} & \multicolumn{3}{|c|}{ left baPWV (cm/sec) } & \multicolumn{3}{|c|}{ PWV range $(\mathrm{cm} / \mathrm{sec})$} \\
\hline & Exercise & Control & diff\% & Exercise & Control & diff\% & Exercise & Control & diff\% \\
\hline Male & $\begin{array}{l}1655.84 \\
(340.93)\end{array}$ & $\begin{array}{l}1703.31 \\
(283.77)\end{array}$ & $2.87 \%$ & $\begin{array}{l}1677.82 \\
(553.91)\end{array}$ & $\begin{array}{l}1684.68 \\
(268.67)\end{array}$ & $0.41 \%$ & $\begin{array}{c}1.82 \\
(0.88)\end{array}$ & $\begin{array}{c}1.76 \\
(0.88)\end{array}$ & $3.30 \%$ \\
\hline Female & $\begin{array}{l}1648.15 \\
(298.24)\end{array}$ & $\begin{array}{l}1788.48 \\
(295.33)\end{array}$ & $8.51 \%$ & $\begin{array}{l}1633.72 \\
(286.89)\end{array}$ & $\begin{array}{l}1761.67 \\
(294.10)\end{array}$ & $7.83 \%$ & $\begin{array}{c}1.75 \\
(0.89)\end{array}$ & $\begin{array}{l}2.08 \\
(0.79)\end{array}$ & $18.86 \%$ \\
\hline
\end{tabular}

All data represents by mean $( \pm S D)$, diff $\%=\{(\text { Control-Exercise }) / \text { Exercise }\}^{*} 100$.

Abbreviation: baPWV, brachial ankle pulse wave velocity.

Table 3. The results of one-way ANOVA on right baPWV

\begin{tabular}{lcccccc}
\hline \multicolumn{1}{c}{ Source } & DF & SS & MS & F & p & Post-hoc $^{*}$ \\
\hline Between Groups & 3 & 472674.084 & 157558.028 & 1.687 & 0.172 & ---------- \\
Within Times & 150 & 14005797.631 & 93371.984 & & d b a c \\
Sum & 153 & 14478471.714 & & & & \\
\hline
\end{tabular}

(continue) The results of one-way ANOVA on left baPWV

\begin{tabular}{lcccccc}
\hline \multicolumn{1}{c}{ Source } & DF & SS & MS & F & p & Post-hoc $^{*}$ \\
\hline Between Groups & 3 & 323123.313 & 107707.771 & 0.782 & 0.506 & ----------- \\
Within Times & 150 & 20654264.037 & 137695.094 & & d b a c \\
Sum & 153 & 20977387.351 & & & \\
\hline
\end{tabular}

(continue) The results of one-way ANOVA on baPWV range

\begin{tabular}{lcccccc}
\hline \multicolumn{1}{c}{ Source } & DF & SS & MS & F & p & Post-hoc $^{*}$ \\
\hline Between Groups & 3 & 2.696 & 0.899 & 1.194 & 0.314 & ---------- \\
Within Times & 150 & 112.869 & 0.752 & & d a b c \\
Sum & 153 & 115.565 & & & \\
\hline
\end{tabular}

*Post-hoc symbol mark: a, b, c, d are represent to an exercised male group, a control male group, an exercised female group, and a control female group respectively.

제군의 right baPWV는 각각 $1648.15( \pm 298.24) \mathrm{cm} / \mathrm{sec}$ 와 $1788.48( \pm 295.33) \mathrm{cm} / \mathrm{sec}$ 씩으로 $8.51 \%$ 의 차이율을 나타내었 다. 이에 대한 Table 3 의 일원변량 분산분석 결과는 집단 간에 통계 적으로 유의한 $\left(\mathrm{F}_{3,150}=1.687, p=0.172\right)$ 차이를 보이지 않는 것으로 나타났다.

(2) 좌측 위팔-발목 맥박파전파속도의 분산분석 및 사후검정 결과 Table 2에 제시된 좌측 위팔-발목 맥박파전파속도(left baPWV) 에 대한 일원변량 분산분석 결과와 이에 대한 Tukey 사후검정 결과 는 Table 3 과 같다. Table 2에서 노인남성 운동군과 통제군의 left $\mathrm{baPWV}$ 는 각각 $1677.82( \pm 553.91) \mathrm{cm} / \mathrm{sec}$ 와 1684.68 ( \pm 268.67$)$ $\mathrm{cm} / \mathrm{sec}$ 씩으로 $0.41 \%$ 의 차이율을 보였고, 노인여성 운동군과 통 제군의 left baPWV는 각각 $1633.72( \pm 286.89) \mathrm{cm} / \mathrm{sec}$ 와 1761.67 $( \pm 294.10) \mathrm{cm} / \mathrm{sec}$ 씩으로 $7.83 \%$ 의 차이율을 나타내었다. 이에 대한 Table 3 의 일원변량 분산분석 결과는 집단 간에 통계적으로 유의한 $\left(\mathrm{F}_{3,150}=0.782, p=0.506\right)$ 차이를 보이지 않는 것으로 나타났다.

(3) 위팔-발목 맥박파전파속도 범위의 분산분석 및 사후검정 결과
Table 2에 제시된 위팔-발목 맥박파전파속도 범위(baPWV range)에 대한 일원변량 분산분석 결과와 이에 대한 Tukey 사후검 정 결과는 Table 3 과 같다. Table 2에서 노인남성 운동군과 통제군 의 baPWV range는 각각 $1.82( \pm 0.88)$ 와 $1.76( \pm 0.88)$ 씩으로 $3.30 \%$ 의 차이율을 보였고, 노인여성 운동군과 통제군의 baPWV range는 각각 $1.75( \pm 0.89)$ 와 $2.08( \pm 0.79)$ 씩으로 $18.86 \%$ 의 차 이율을 나타내었다. 이에 대한 Table 3 의 일원변량 분산분석 결과 는 집단 간에 통계적으로 유의한 $\left(\mathrm{F}_{3,150}=1.194, p=0.314\right)$ 차이를 보 이지 않는 것으로 나타났다.

\section{2) 집단별 신체구성 변인의 차이}

실험 종료 후 집단별 신체구성 변인에 대한 평균과 표준편차는 Table 4와 같으며, 이에 대한 일원변량 분산분석과 사후검정의 결 과는 Table 5 와 같다.

(1) 요둔위(WHR) 의 분산분석 및 사후검정 결과

Table 4에 제시된 요둔위(WHR)에 대한 일원변량 분산분석 결 
382 Jong-Woo Lee, et al. Correlation and Differences on Cardiovascular-Related Factors in Elderly

Table 4. Differences of body composition variables among total groups

\begin{tabular}{|c|c|c|c|c|c|c|c|c|c|}
\hline \multirow{3}{*}{ Genders } & \multicolumn{9}{|c|}{ Groups } \\
\hline & \multicolumn{3}{|c|}{ WHR } & \multicolumn{3}{|c|}{ Muscle mass (kg) } & \multicolumn{3}{|c|}{ \%Body fat (\%) } \\
\hline & Exercise & Control & diff\% & Exercise & Control & diff\% & Exercise & Control & $\operatorname{diff} \%$ \\
\hline Male & $0.91(0.04)$ & $0.90(0.05)$ & $1.09 \%$ & $27.21(2.83)$ & $25.91(2.74)$ & $4.77 \%$ & $27.34(5.47)$ & $26.67(5.99)$ & $2.45 \%$ \\
\hline Female & $0.86(0.06)$ & $0.86(0.04)$ & $0 \%$ & $19.49(2.01)$ & $19.81(3.81)$ & $1.64 \%$ & $36.83(6.68)$ & $37.37(6.20)$ & $1.46 \%$ \\
\hline
\end{tabular}

All data represents by mean $( \pm \mathrm{SD})$, diff $\%=\{(\text { Control-Exercise }) / \text { Exercise }\}^{\star} 100$.

Abbreviation: WHR, waist \& hip ratio.

Table 5. The results of one-way ANOVA on WHR (waist \& hip ratio)

\begin{tabular}{lcccccc}
\hline \multicolumn{1}{c}{ Source } & DF & SS & MS & F & p & Post-hoc $^{*}$ \\
\hline Between Groups & 3 & 0.080 & 0.027 & 9.197 & 0.000 & --------- \\
Within Times & 150 & 0.435 & 0.003 & & a b d c \\
Sum & 153 & 0.515 & & & \\
\hline
\end{tabular}

(continue) The results of one-way ANOVA on muscle mass

\begin{tabular}{lcccccc}
\hline \multicolumn{1}{c}{ Source } & DF & SS & MS & F & p & Post-hoc $^{*}$ \\
\hline Between Groups & 3 & 1881.529 & 627.176 & 74.295 & 0.000 & -------- \\
Within Times & 150 & 1266.250 & 8.442 & & a b d c \\
Sum & 153 & 3147.779 & & & \\
\hline
\end{tabular}

(continue) The results of one-way ANOVA on \%body fat

\begin{tabular}{lcccccc}
\hline \multicolumn{1}{c}{ Source } & DF & SS & MS & F & p & Post-hoc* $^{*}$ \\
\hline Between Groups & 3 & 3922.523 & 1307.508 & 35.045 & 0.000 & --------- \\
Within Times & 150 & 5596.416 & 37.309 & & $\mathrm{~d} \mathrm{c} \mathrm{a} \mathrm{b}$ \\
Sum & 153 & 9518.940 & & & \\
\hline
\end{tabular}

*'See Table 3.'

Abbreviation: WHR, waist \& hip ratio.

과와 이에 대한 Tukey 사후검정 결과는 Table 5와 같다. Table 4에 서 노인남성 운동군과 통제군의 WHR은 각각 $0.91( \pm 0.04)$ 와 0.90 ( \pm 0.05 씩으로 $1.09 \%$ 의 차이율을 보였고, 노인여성 운동군 과 통제군의 WHR은 각각 $0.86( \pm 0.06)$ 과 0.86 ( \pm 0.04$)$ 씩으로 차 이가 없는 것으로 나타났다. 이에 대한 Table 5의 일원변량 분산분 석 결과는 집단 간에 통계적으로 유의한 $\left(\mathrm{F}_{3,150}=9.197, p=0.000\right)$ 차 이를 나타내었으며, 사후검정 결과 노인남성 운동군과 노인여성 통 제군, 노인여성 운동군간에 차이가 있으며, 또 노인남성 통제군과 노인여성 통제군, 노인여성 운동군간에 차이가 있는 것으로 입증되 었다.

\section{(2) 근육량의 분산분석 및 사후검정 결과}

Table 4에 제시된 근육량에 대한 일원변량 분산분석 결과와 이 에 대한 Tukey 사후검정 결과는 Table 5 와 같다.

Table 4에서 노인남성 운동군과 통제군의 근육량은 각각 27.21 $( \pm 2.83) \mathrm{kg}$ 와 $25.91( \pm 2.74) \mathrm{kg}$ 씩으로 $4.77 \%$ 의 차이율을 보였 고, 노인여성 운동군과 통제군의 근육량은 각각 $19.49( \pm 2.01) \mathrm{kg}$ 과 $19.81( \pm 3.81) \mathrm{kg}$ 씩으로 $1.64 \%$ 의 차이율을 나타내었다. 이에
대한 Table 5의 일원변량 분산분석 결과는 집단 간에 통계적으로 유의한 $\left(\mathrm{F}_{3,150}=74.295, p=0.000\right)$ 차이를 나타내었으며, 사후검정 결과 노인남성 운동군과 노인여성 통제군, 노인여성 운동군간에 차 이가 있으며, 또 노인남성 통제군과 노인여성 통제군, 노인여성 운 동군간에 차이가 있는 것으로 입증되었다.

(3) 체지방율의 분산분석 및 사후검정 결과

Table 4에 제시된 체지방율에 대한 일원변량 분산분석 결과와 이에 대한 Tukey 사후검정 결과는 Table 5와 같다. Table 4에서 노 인남성 운동군과 통제군의 체지방율은 각각 $27.34( \pm 5.47) \%$ 와 26.67 ( \pm 5.99$) \%$ 씩으로 $2.45 \%$ 의 차이율을 보였고, 노인여성 운동 군과 통제군의 체지방율은 각각 $36.83( \pm 6.68) \%$ 와 $37.37( \pm 6.20) \%$ 씩으로 $1.46 \%$ 의 차이율을 나타내었다. 이에 대한 Table 5 의 일원변 량 분산분석 결과는 집단 간에 통계적으로 유의한 $\left(\mathrm{F}_{3,150}=35.045\right.$, $p=0.000$ ) 차이를 나타내었으며, 사후검정 결과 노인여성 통제군과 노인남성 운동군, 노인남성 통제군간에 차이가 있으며, 또 노인여 성 운동군과 노인남성 운동군, 노인남성 통제군간에 차이가 있는 것으로 입증되었다. 


\section{3) 집단별 심혈관계 변인의 차이}

실험 종료 후 집단별 심혈관계 변인에 대한 평균과 표준편차는 Table 6과 같으며, 이에 대한 일원변량 분산분석과 사후검정의 결 과는 Table 7과 같다.

(1) 수축기 혈압의 분산분석 및 사후검정 결과

Table 6에 제시된 수축기혈압(SBP) 에 대한 일원변량 분산분석 결과와 이에 대한 Tukey 사후검정 결과는 Table 7과 같다. Table 6 에서 노인남성 운동군과 통제군의 수축기혈압은 각각 127.53 $( \pm 10.33) \mathrm{mmHg}$ 와 $120.89( \pm 13.85) \mathrm{mmHg}$ 씩으로 $5.20 \%$ 의 차 이율을 보였고, 노인여성 운동군과 통제군의 수축기혈압은 각각 $121.10( \pm 15.08) \mathrm{mmHg}$ 와 $127.78( \pm 10.78) \mathrm{mmHg}$ 씩으로 $5.51 \%$ 의 차이율을 나타내었다. 이에 대한 Table 7 의 일원변량 분산분석 결과는 집단 간에 통계적으로 유의한 $\left(\mathrm{F}_{3,150}=3.525, p=0.017\right)$ 차이 를 나타내었으나, 사후검정 결과 집단 간에 차이가 없는 것으로 나 타났다.

(2) 이완기 혈압의 분산분석 및 사후검정 결과

Table 6에 제시된 이완기혈압(DBP)에 대한 일원변량 분산분석
결과와 이에 대한 Tukey 사후검정 결과는 Table 7과 같다. Table 6 에서 노인남성 운동군과 통제군의 이완기혈압은 각각 82.00 $( \pm 6.56) \mathrm{mmHg}$ 와 79.89 ( \pm 9.27$) \mathrm{mmHg}$ 씩으로 $2.57 \%$ 의 차이율 을 보였고, 노인여성 운동군과 통제군의 이완기혈압은 각각 79.80 $( \pm 7.85) \mathrm{mmHg}$ 와 $84.00( \pm 6.73) \mathrm{mmHg}$ 씩으로 $5.26 \%$ 의 차이율 을 나타내었다. 이에 대한 Table 7 의 일원변량 분산분석 결과는 집 단 간에 통계적으로 유의한 $\left(\mathrm{F}_{3,150}=2.554, p=0.058\right)$ 차이를 나타내 지 않았고, 사후검정 결과에서도 집단 간에 차이가 없는 것으로 나 타났다.

(3) 심박수의 분산분석 및 사후검정 결과

Table 6에 제시된 심박수(HR)에 대한 일원변량 분산분석 결과 와 이에 대한 Tukey 사후검정 결과는 Table 7과 같다. Table 6에서 노인남성 운동군과 통제군의 심박수는 각각 62.97 ( \pm 7.04$)$ beats $/ \mathrm{min}$ 과 64.84 ( \pm 10.81$)$ beats $/ \mathrm{min}$ 씩으로 $2.96 \%$ 의 차이율 을 보였고, 노인여성 운동군과 통제군의 심박수는 각각 67.35 ( \pm 7.73$)$ beats $/ \mathrm{min}$ 과 $66.78( \pm 10.18)$ beats $/ \mathrm{min}$ 씩으로 $0.84 \%$ 의 차이율을 나타내었다. 이에 대한 Table 7 의 일원변량 분산분석

Table 6. Differences of cardiovascular variables among total groups

\begin{tabular}{|c|c|c|c|c|c|c|c|c|c|}
\hline \multirow{3}{*}{ Genders } & \multicolumn{9}{|c|}{ Groups } \\
\hline & \multicolumn{3}{|c|}{$\mathrm{SBP}(\mathrm{mmHg})$} & \multicolumn{3}{|c|}{ DBP (mmHg) } & \multicolumn{3}{|c|}{ HR (beats/min) } \\
\hline & Exercise & Control & diff\% & Exercise & Control & diff\% & Exercise & Control & $\operatorname{diff} \%$ \\
\hline Male & $127.53(10.33)$ & $120.89(13.85)$ & $5.20 \%$ & $82.00(6.56)$ & 79.89 (9.27) & $2.57 \%$ & $62.97(7.04)$ & $64.84(10.81)$ & $2.96 \%$ \\
\hline Female & 121.10 & $127.78(10.78)$ & $5.51 \%$ & $79.80(7.85)$ & $84.00(6.73)$ & $5.26 \%$ & $67.35(7.73)$ & $66.78(10.18)$ & $0.84 \%$ \\
\hline
\end{tabular}

All data represents by mean $( \pm S D)$, diff(difference) $\%=\left\{(\right.$ Control-Exercise $) /$ Exercise ${ }^{\star} 100$.

Abbreviaton: SBP, systolic blood pressure; DBP, diastolic blood pressure; HR, heart rate.

Table 7. The results of one-way ANOVA on SBP

\begin{tabular}{|c|c|c|c|c|c|c|}
\hline Source & DF & SS & MS & $\mathrm{F}$ & $p$ & Post-hoc* \\
\hline Between Groups & 3 & 1708.287 & 569.429 & 3.525 & 0.017 & ------------- \\
\hline Within Times & 150 & 24231.142 & 161.541 & & & $d a c b$ \\
\hline Sum & 153 & 25939.429 & & & & \\
\hline \multicolumn{7}{|c|}{ (continue) The results of one-way ANOVA on DBP } \\
\hline Source & DF & SS & MS & $\mathrm{F}$ & $p$ & Post-hoc* \\
\hline Between Groups & 3 & 452.644 & 150.881 & 2.554 & 0.058 & ------------- \\
\hline Within Times & 150 & 8861.979 & 59.080 & & & $d a b c$ \\
\hline Sum & 153 & 9314.623 & & & & \\
\hline \multicolumn{7}{|c|}{ (continue) The results of one-way ANOVA on HR } \\
\hline Source & DF & SS & MS & $\mathrm{F}$ & $p$ & Post-hoc* \\
\hline Between Groups & 3 & 463.077 & 154.359 & 1.886 & 0.134 & ------------- \\
\hline Within Times & 150 & 12277.397 & 81.849 & & & $c d b a$ \\
\hline Sum & 153 & 12740.474 & & & & \\
\hline
\end{tabular}

*'See Table 3.'

Abbreviaton: 'See Table 6.' 


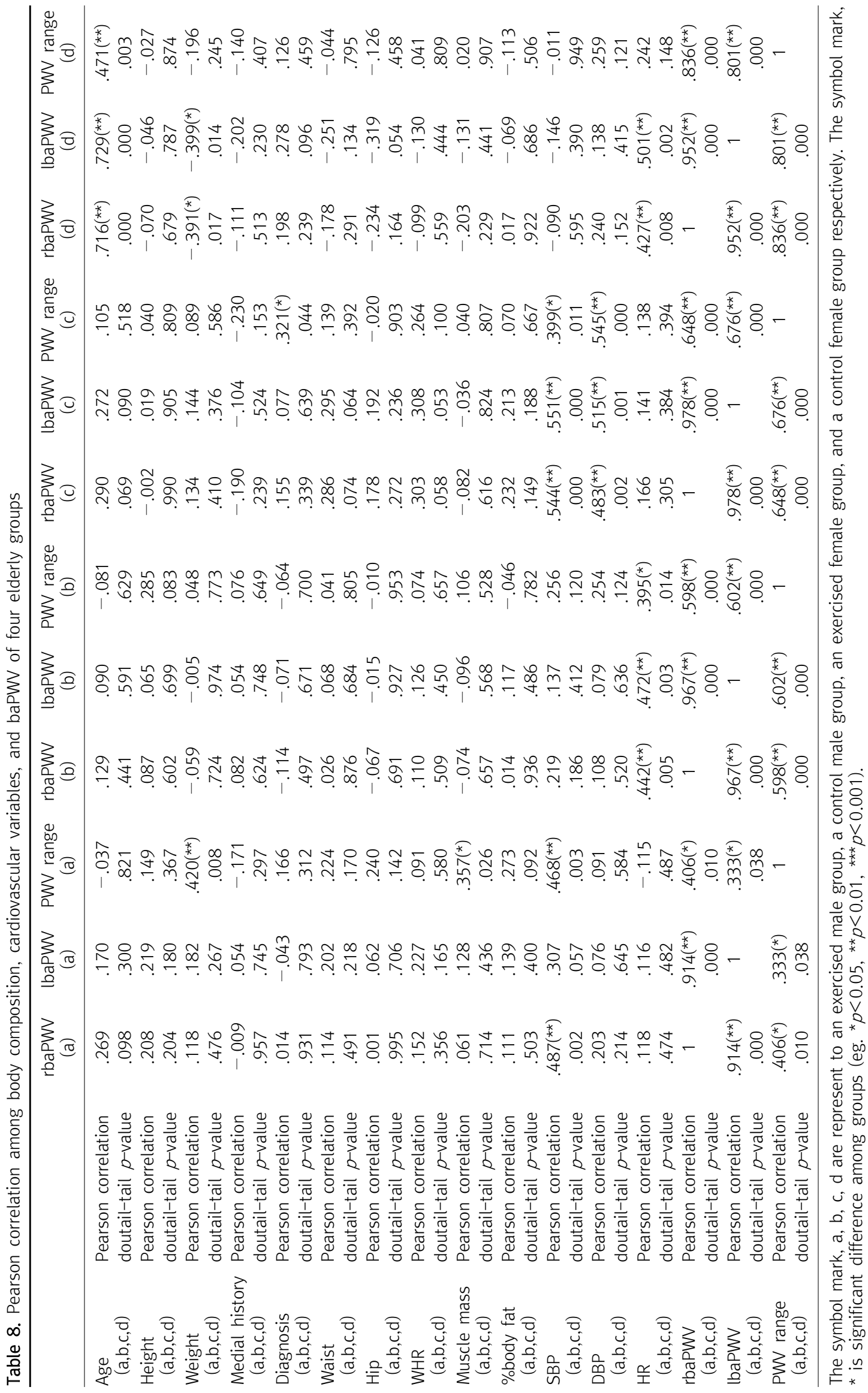


결과는 집단 간에 통계적으로 유의한 $\left(\mathrm{F}_{3,150}=1.886, p=0.134\right)$ 차이 를 나타내지 않았고, 사후검정 결과에서도 집단 간에 차이가 없는 것으로 나타났다.

\section{2. 집단별 위팔-발목 맥박파전파속도와 신체구성, 심혈관계 변인간의 상관성}

각 변인들의 측정 종료 후 집단별 말초동맥파속도와 신체구성, 심혈관계 변인간에 상관관계는 제시된 Table 8 과 같다. 규칙적인 운동을 수행해온 노인남성의 위팔-발목 맥박파전파속도와 신체구 성, 심혈관계 변인간에 통계적으로 유의한 상관관계를 보인 변인으 로는 체중과 PWV range ( $\mathrm{r}=0.420, p=0.008)$, 근육량과 $\mathrm{PWV}$ range ( $\mathrm{r}=0.357, p=0.026), \mathrm{SBP}$ 와 $\mathrm{DBP}(\mathrm{r}=0.419, p=0.008), \mathrm{SBP}$ 와 $\mathrm{rbaPWV}(\mathrm{r}=0.487, p=0.002), \mathrm{SBP}$ 와 $\mathrm{PWV}$ range ( $\mathrm{r}=0.468$, $p=0.003), \mathrm{rbaPWV}$ 와 $\mathrm{lbaPWV}(\mathrm{r}=0.914, p=0.000), \mathrm{rbaPWV}$ 와 $\mathrm{PWV}$ range ( $\mathrm{r}=0.406, p=0.010), \mathrm{lbaPWV}$ 와 $\mathrm{PWV}$ range $(\mathrm{r}=0.333$, $p=0.038)$ 이다.

규칙적인 운동을 수행해 오고 있지 않았던 노인남성의 위팔-발 목 맥박파전파속도와 신체구성, 심혈관계 변인간 통계적으로 유의 한 상관관계를 보인 변인으로는 심박수와 $\mathrm{rbaPWV}(\mathrm{r}=0.442$, $p=0.005)$, 심박수와 $1 \mathrm{baPWV}(\mathrm{r}=0.472, p=0.003)$, 심박수와 $\mathrm{PWV}$ range $(\mathrm{r}=0.395, p=0.014)$, rbaPWV와 $1 \mathrm{baPWV}(\mathrm{r}=0.967, p=0.000)$, $\mathrm{rbaPWV}$ 와 PWV range ( $\mathrm{r}=0.3598 p=0.000), \mathrm{lbaPWV}$ 와 $\mathrm{PWV}$ range $(\mathrm{r}=0.602, p=0.000)$ 이다.

규칙적인 운동을 수행해온 노인여성의 위팔-발목 맥박파전파 속도, 신체구성, 심혈관계 변인간에 통계적으로 유의한 상관관계 를 보인 변인으로는 진단명과 $\mathrm{PWV}$ range $(\mathrm{r}=0.321 p=0.044)$, $\mathrm{SBP}$ 와 $\mathrm{rbaPWV}(\mathrm{r}=0.544 p=0.000), \mathrm{SBP}$ 와 $\mathrm{lbaPWV}(\mathrm{r}=0.551$ $p=0.000), \mathrm{SBP}$ 와 $\mathrm{PWV}$ range ( $\mathrm{r}=0.399 p=0.011), \mathrm{DBP}$ 와 $\mathrm{rbaPWV}$ $(\mathrm{r}=0.483 p=0.002)$, DBP와 $\mathrm{lbaPWV}(\mathrm{r}=0.515 p=0.001)$, DBP와 PWV range ( $\mathrm{r}=0.545 p=0.000)$, $\mathrm{rbaPWV}$ 와 $\mathrm{lbaPWV}(\mathrm{r}=0.978$ $p=0.000), \mathrm{rbaPWV}$ 와 $\mathrm{PWV}$ range ( $\mathrm{r}=0.648 p=0.000), \mathrm{baPWV}$ 와 $\mathrm{PWV}$ range $(\mathrm{r}=0.676 p=0.000)$ 이다.

규칙적인 운동을 수행해 오고 있지 않았던 노인여성의 위팔-발 목 맥박파전파속도, 신체구성, 심혈관계 변인간 통계적으로 유의 한 상관관계를 보인 변인으로는 연령과 $\mathrm{rbaPWV}(\mathrm{r}=0.716$ $p=0.000)$, 연령과 $\mathrm{lbaPWV}(\mathrm{r}=0.729 p=0.000)$, 연령과 $\mathrm{PWV}$ range ( $\mathrm{r}=0.471 p=0.003)$, 체중과 $\mathrm{rbaPWV}(\mathrm{r}=-0.391 p=0.017)$, 체중과 $1 \mathrm{baPWV}(\mathrm{r}=-0.399 p=0.014)$, 심박수와 $\mathrm{rbaPWV}(\mathrm{r}=0.427$ $p=0.008)$, 심박수와 $\mathrm{lbaPWV}(\mathrm{r}=0.501 p=0.002), \mathrm{rbaPWV}$ 와 lbaPWV ( $\mathrm{r}=0.952 p=0.000)$, rbaPWV와 PWV range $(\mathrm{r}=0.836$ $p=0.000), \mathrm{lbaPWV}$ 와 PWV range ( $\mathrm{r}=0.801 p=0.000)$ 이다.

\section{고 찰}

노인들의 건강은 단순히 질병의 유무에 국한되는 것이 아니라, 기능의 유무가 매우 중요한 의미를 지닌다. 노인의 기능들 중 규칙 적인 운동은 신체기능을 향상시키고 여러 질환의 발병률을 낮추며 노화와 연관되는 기능저하의 시기를 늦추는데 있어 가장 효과적이 고 경제적인 방법으로 거론되고 있다[14]. 이와 같은 맥락에서 Ehsani 등 [15]의 연구에 의하면 규칙적인 운동은 좌심실 수축기능 의 향상을 가져와최대운동시 박출율(ejection fraction), 1 회 박출 량(stroke volume), 심근 산소요구량(rate pressure product, $\mathrm{RPP})$ 등을 증가시키며, 심근의 혈관증가와 모세혈관 밀도증가, 관 상동맥 주부 및 측부 내경의 증대를 가져온다고 보고한 바 있다. 선 행연구들을 살펴보면 질병과 사망률에 신체적 활동과 유산소성 운 동 능력이 명확히 영향을 주며[16], 관상동맥질환을 포함한 격심한 만성적 질환들을[17] 예방하기 위해 규칙적인 신체활동을 제안하 였다[18]. 대다수의 선행연구에서도 규칙적인 유산소성 운동은 고 혈압, 비만, 당뇨병 등에 기인한 관상동맥질환(coronary heart disease, CHD)을 예방하거나 그 위험 요인을 감소시켜 줄 뿐만 아 니라, 심폐기능(cardiorespiratory function)을 강화시킨다고 보 고하고 있다[19]. 동맥의 경화도는 다른말로 순응도(compliance) 이나 탄성(elasticity)으로도 표현되는데 맥박파전파속도(pulse wave velocity, PWV)는 동맥의 두지점 사이를 통과하는 맥파의 속도로, 동맥 경직도의 표지자로 근래 많이 사용되고 있으며[8], 대 표적인 동맥벽 경화도의 지표로써 국제적으로 통용되고 있다[9]. $\mathrm{PWV}$ 와 운동에 관한 선행논문을 살펴보면, Alan 등[20]은 정상인 의 유산소성 운동이 심박출량의 증가에 따라 혈관의 탄성(Forearm vascular compliance, FVC)이 증가하는 것으로 보고 하였고, Tanaka 등[21]은 평소의 운동습관이 PWV에 영향을 줄 수 있으며 젊은 층 및 폐경후의 여성에서 운동습관의 유무에 의한 대동맥 $\mathrm{PWV}$, 경동맥 증가지수(Augmentation Index)등을 비교하여 운 동습관이 있는 여성에서는 연령증가에 따른 동맥벽의 경화가 보이 지 않는다고 보고하였다. Mohiaddin 등[22]은 지구성 트레이닝을 계속하는 운동선수의 동맥신전성은 일반 대상자 보다 크다고 하였 고, Mohiaddin 등[22]과 Tanaka 등[13]의 연구에서는 PWV는 연 령증가와 함께 증대하나, 운동선수뿐만 아니라 일상의 신체 활동량 이 많은 일반 대상자에서도, 연령증가와 함께 PWV의 증대가 억제 되고 있는 것을 볼 수 있었다. 다양한 비침습적 진단법은 최근의 잠 재적, 무증상기의 질병에 대한 관심이 높아지고 심혈관 질환의 예 방에 대한 중요성이 대두되면서 더욱 주목받게 되었다[23]. 기존에 는 전신 동맥경화증의 지표로서 맥박파전파속도의 계측이 실시되 어 왔으나[24], 최근에는 대동맥 측정의 기술적 용이성과 재현도가 
보완된 위팔-발목 맥박파전파속도를 측정함으로 여러 임상적 평가 지표와 함께 심혈관 질환의 예측인자이자 중증도 평가지표로서 활 용되고 있다[25]. 본 연구에서 관찰한 노인들의 경우 집단별 재변인 간의 차이를 밨을 때 위팔-발목 맥박파전파속도 변인 중 통계적으 로 유의한 차이를 보인 변인은 없는 것으로 나타났고, 신체구성 변 인 중 통계적으로 유의한 차이를 보인 변인은 요둔위 $\left(\mathrm{F}_{3,150}=9.197\right.$, $p=0.000)$, 근육량 $\left(\mathrm{F}_{3,150}=74.295, p=0.000\right)$, 체지방율 $\left(\mathrm{F}_{3,150}=35.045\right.$, $p=0.000$ )로 나타났으며, 심혈관계 변인 중 통계적으로 유의한 차 이를 보인 변인은 수축기 혈압 $\left(\mathrm{F}_{3,150}=3.525, p=0.017\right)$ 으로 나타났 다. 위팔-발목 맥박파전파속도가 운동군 노인남성의 경우 체중, 근 육량, 수축기혈압과 유의한 상관성을 보였고, 통제군 노인남성의 경우는 위팔-발목 맥박파전파속도와 좌우측 위팔-발목 맥박파전 파속도와의 유의한 상관성 외에 기타 다른 변인과의 유의한 상관성 을 나타낸 변인은 없었다. 한편, 운동군 노인여성의 경우는 위팔-발 목 맥박파전파속도와 진단명, 수축기혈압, 이완기혈압과 유의한 상관성이 있었고, 통제군 노인여성의 경우에는 연령, 체중, 심박수 와 유의한 상관성이 있는 것으로 나타나 집단별 특성에 따라 다양 한 결과가 나타난다는 사실을 알 수가 있었다. 이러한 결과는 결국 본 연구의 피험자로 참여하였던 노인들이 모두 수축기혈압이 정상 범위에 있었기 때문에 그 민감성이 다소 떨어져 위팔-발목 맥박파 전파속도와의 유의한 상관성이 다양하게 나타난 것으로 생각된다. 한편 본 연구의 한계점으로는 $\mathrm{A}$ 시에 거주하고 있는 60 세 이상 노인 들로만 한정하였으며, 모든 피험자들의 생활습관, 음주습관, 흡연 습관, 심리적요인, 식생활, 유전적인 요인 등을 동일하게 통제하지 못하였다. 본 연구에서 관찰한 신체구성 변인과 심혈관계 변인 중 수축기 혈압은 운동 여부에 따라 민감한 변화와 차이를 보인 것으 로 보아 노인의 경우 운동이라는 매개체가 신체구성과 심혈관계 일 부 변인에 변화를 줄수 있다고 단정지어 볼 수 있겠으나, 위팔-발목 맥박파전파속도에 대해서는 일관된 결과가 도출되지 않아서 이에 대한 지속적인 연구가 필요한 것으로 사료된다.

\section{요 약}

심혈관계 위험인자를 비침습적으로 분석할 수 있는 PWV에 관 한 다수의 선행연구에서 의견이 분분하고, 결과에 대한 일관성이 부족한 부분을 재현하고자 연구에 임하였으며, 더욱이 날로 증가하 고 있는 노인을 대상으로 운동참여 여부와 성별에 따른 노인의 말 초동맥파속도(baPWV), 신체구성과 심혈관계 변인의 상관성 및 재 변인의 차이를 검증하는데 연구의 목적이 있다. 규칙적인 운동을 수행해온 노인남성 39명(이하, 운동군M) 과 운동을 수행해 오고 있 지 않은 동일 연령대의 노인남성 38명(이하, 통제군M), 규칙적인
운동을 수행해온 노인여성 40 명(이하, 운동군F) 과 운동을 수행해 오고 있지 않은 동일 연령대의 노인여성 37명(이하, 통제군F)을 대 상으로 변인에 대한 상관성과 집단별 재변인들 간의 차이를 알아본 결과 노인남성 운동군의 $\mathrm{baPWV}$ range와 근육량 $(\mathrm{r}=0.357$, $p=0.026)$, 수축기혈압( $(\mathrm{r}=0.468, p=0.003), \mathrm{rbaPWV}(\mathrm{r}=0.406$, $p=0.010), \mathrm{lbaPWV}(\mathrm{r}=0.333, p=0.038$ )가 통계적으로 유의한 상 관관계를 보였고, 노인남성 통제군의 경우는 baPWV range와 심 박수( $\mathrm{r}=0.395, p=0.014), \mathrm{rbaPWV}(\mathrm{r}=0.598, p=0.000), \mathrm{lbaPWV}$ $(\mathrm{r}=0.602, p=0.000)$ 가 유의한 상관성을 보였다. 노인여성 운동군 은 $\mathrm{baPWV}$ range와 진단명 $(\mathrm{r}=0.321, p=0.044)$, 수축기혈압 $(\mathrm{r}=0.399, p=0.011)$, 이완기혈압 $(\mathrm{r}=0.545, p=0.000), \mathrm{rbaPWV}$ $(\mathrm{r}=0.648, p=0.000), \mathrm{lbaPWV}(\mathrm{r}=0.676, p=0.000)$ 가 유의한 상관 성을 보였고, 노인여성 통제군 경우는 baPWV range와 나이 $(\mathrm{r}=0.471, p=0.003), \mathrm{rbaPWV}(\mathrm{r}=0.836, p=0.000), \mathrm{lbaPWV}$ $(\mathrm{r}=0.801, p=0.000)$ 가 통계적으로 유의한 상관성을 보였다. 반면 말초동맥파속도 변인 중 통계적으로 유의한 차이를 보인 그룹은 없는 것으로 나타났고, 요둔위 $\left(\mathrm{F}_{3,150}=9.197, p=0.000\right)$, 근육량 $\left(\mathrm{F}_{3,150}=74.295, p=0.000\right)$, 체지방율 $\left(\mathrm{F}_{3,150}=35.045, p=0.000\right)$, 수 축기 혈압 $\left(\mathrm{F}_{3,150}=3.525, p=0.017\right)$ 이 통계적으로 유의한 차이를 나 타냈다. 본 연구에서는 집단별 특성에 따라 다양한 결과가 나타난 다는 사실을 알 수 가 있었으며, 신체구성 변인과 심혈관계 변인 중 수축기 혈압은 운동 여부에 따라 민감한 변화와 차이를 보인 것으 로 보아 노인의 경우 운동그룹은 신체구성과 심혈관계 일부 변인에 변화를 줄 수 있다고 단정지어 볼 수 있겠으나, 위팔-발목 맥박파전 파속도에 대해서는 일관된 결과가 도출되지 않아서 이에 대한 지속 적인 연구가 필요한 것으로 사료된다.

\section{Acknowledgements: None}

Funding: None

Conflict of interest: None

\section{References}

1. Castelli WP. Epidemiology of coronary heart disease: The framingham study. Am J Med. 1984;76:4-11.

2. McGovern PG, Pankow JS, Shahar E, Doliszny KM, Folsom AR, Blackburn H, et al. Recent trends in acute coronary heart disease: mortality, morbidity, medical care and risk factors mortality, morbidity, medical care, and risk factors. $\mathrm{N}$ Eng J Med. 1996;334:884-890.

3. Cherubini A, Lowenthal DT, Williams LS, Maggio D, Mecocci P, Senin U. Physical activity and cardiovascular health in the elderly. Aging Clin Exp Res. 1998;10:13-25.

4. Makrides L, Heigenhauser GJF, Jones NL. Hight-intensity en- 
durance training in 20-to 30-and 60-to 70-yr-old health men. J Applied Physiology. 1990;69(5):1792-1798.

5. Kohrt WM, Malley MT, Coggan AR, Spina RJ, Ogawa T, Ehsani $\mathrm{AA}$, et al. Effect of gender, age, and fitness level on response of VO2max to training to 60-71years old. J Applied Physiology. 1991;71:2001-2004.

6. Duprez DA, Somasundaram PE, Sigurdsson G, Hoke L, Florea N, Cohn JN, et al. Relationship between c-reactive protein and arterial stiffness in asymptomatic population. J Human Hypertension. 2005;19:515-519.

7. Eileen CL. Update on selected markers used in risk assessment of vascular disease. Clin Lab Sci. 2004;17:43-49.

8. O'Neal DN, Dragicevic G, Rowley KG, Ansari MZ, Balazs N, Jenkins A, et al. A cross-sectional study of the effects of type 2 diabetes and other cardiovascular risk factors on structure and function of nonstenotic arteries of the lower limb. Diabetes Care. 2003;26:199-205.

9. Asmar R. Arterial stiffness and pulse wave velocity. 1st ed. Paris: Elsevier SAS; 1999. p67-93.

10. Kennedy CM, Lisa R, Simon GA, John SW, Graham D, Ray GG. Aortic pulse-wave velocity and its relationship to mortality in diabetes and glucose intolerance. Circulation. 2002;106:20852090.

11. Laurent S, Boutouyrie P, Asmar R, Gautier I, Laloux B, Guize L, et al. Aortic stiffness is an independent predictor of all-cause and cardiovascular mortality in hypertensive patients. Hypertension. 2001;37:1236-1241.

12. Nichols WW, O'Rourke MF. McDonald's blood flow in arteries. Theoretical, experimental and clinical principles. 4th ed. London: Hodder Arnold; 1998. p595-625.

13. Tanaka H, Dinenno FA, Monahan KD, Clevenger CM, DeSouza CA, Seals DR. Aging, habitual exercise, and dynamic arterial compliance. Circulation. 2000;102:1270-1275.

14. Walter M, Bortz II. Disuse and aging. JAMA. 1982;248:12031208.

15. Ehsani AA, Hagberg JM, Hickson RC. Rapid changes in left ventricular dimension and mass in response to physical conditioning and deconditioning. Am J Cardiol. 1978;42:52-56.

16. Paffenbarger RS, Hyde RT, Wing AL, Lee IM, Jung D, Kampert
JB. The association of changes in physical activity level and other lifestyle characteristics with mortality among men. N Eng J Med. 1993;328:538-545.

17. Powell KE, Thompson PD, Casperse CJ, Ford ES. Physical activity and the incidence of coronary heart disease. Ann Rev Public Health. 1987;8:253-287.

18. Pate RR, Pratt M, Blai SN, Haskell WL, Macera CA, Bouchard C, et al. Physical activity and public health. A recommendation from the centers for disease control and prevention and the american college of sports medicine. JAMA. 1995;273:402-407.

19. Spina RJ, Ogawa T, Miller TR, Kohrt WM, Ehsani AA. Effect of exercise training on left ventricular performance in older women free of cardiopulmonary disease. Am J Cardiol. 1993;71:99104.

20. Alan R, Ehtasham Q, Mara B, George R, Giora P, George AD. Peripheral arterial responses to treadmill exercise among healthy subjects and atherosclerotic patients. Circulation. 2001;106:2084-2089.

21. Tanaka H, DeSouza CA, Seals DR. Absence of age-related increase in central arterial stiffness in physically active women. Arterioscler Thromb Vasc Biol. 1998;18:127-132.

22. Mohiaddin RK, Underwood SR, Borgen HG, Firmin DN, Klipstein RH, Ress SR, et al. Regional aortic compliance studied by magnetic resonance imaging: the effect of age, training and cornary artery disease. Br Heart J. 1989;62:90-96.

23. Irene MM, Michie LB, Albert H, Antonio IS, Deirdre AMK, Jacqueline CMW. Predictive value of noninvasive measure of atherosclerosis for incident myocardio infarction: the rotterdam study. Circulation. 2004;109:1089-1094.

24. Laurent S, Boutouyrie P, Asmar R, Gautier I, Laloux B, Guize L, et al. Aortic stiffness is an independent predictor of all-cause and cardiovascular mortality in hypertensive patients. Hypertension. 2001;37:1236-1241.

25. Yutaka K, Hirofumi T, Hiroaki I, Tsuneyuki N, Nobuhiro T, Kenji $\mathrm{T}$, et al. Comparison of ankle-brachial pressure index and pulse wave velocity as markers of the presence of coronary artery disease in subjects with a high risk of atherosclerotic caridovascular disease. Am J Cardiol. 2004;94:868-872. 